\title{
「雪国における居住地計画」に関する文献研究 一居住地計画の到達点と問題点一
}

\section{1. 研究目的}

我国の多雪地における居住地計画研究は，緒につ いたばかりで既存研究の到達点の把握は元より，そ の全体像の解明及び方向付けも明確化されていない。 最近，ポスト新幹線上多雪地では屋根雪処理に対 する関心か滈まっているが, 人力雪下ろしを前提と して形成された多雪地の住宅及び街並み・村並み居 住空間はそれを根本的に变えて行かないと，「雪下 ろしからの解放」は覚束無い。他方，雪国には，地 域性や因習・慣習・伝統等が強いため，その地域に 合った提案をきめ細かく行っていかないと「物」だ けの整備に終り，その結果豊かな地域生活文化を破 壊してしまう恐れがある。

よころで, 各地の研究者は長年にわたる多雪地に おける研究活動を通じて多数の文献及び資料を収葉 している。しかし，それは個人的な収集であり，夫々 バラバラで偏りがある。又，例えば，「雪国におけ る居住地計画」に関する研究を若い研究者か新規に 始めようとした場合，どこによ゙のような文献があり， どのような研究ジャンルがあり，夫々どの位の研究 成果があり，到達しているのかが判らないと，研究 に着手のしようる無いのか現実である。従って，同 志が交流して情報交換し合いながら，個々バラバラ な文献を一堂に集め，欠落している物を補充し，到 達点之問題点を整理し，緒についたばかりの「雪国 における居住地計画」に関する克雪建築や克雪宅地 計画等のハード面と，雪国居住等のソフト面の両面 の研究の全体像を解明することと，その分野の研究

\section{深 澤 大 輔*}

を推進して行く体制を確立することは，現在最も重 要な課題と考え，研究に着手した。

そこで，本研究では先ず，「雪国における居住地 計画」に関する文献を収集し，次にその研究ジャン ルを探り，そのジャンル別にシソーラスを作成し， キーワード（標準ディスクプリ夕）を選定して，カー ド型データベースソフトに文献を入力し，キーワー ドによる文献検索が可能となるようにした。これに よりこの分野の研究活動にオリエンテーションを 与え,「雪国における居住地計画」研究を活発化さ せ，雪国の居住地整備に関する基礎資料を提供する ことを狙いとした。そのために，「雪国の居住地計 画研究会（代表・深澤大輔）」を組織し，(財）住綿 研からの研究助成を受けて，各地に分散している研 究者等の交流を行い，国の内外の文献を一望できる 「文献集」を作成することとした。

これにより「雪国における居住地站十画」研究の夕ー ゲットを見定め，この分野の研究を進め，多雪地域 独自の居住地計画の樹立を計ることは，最近大きな 社会問題と化している多雪地の居住地整備の推進に とって緊急の課題である。又，このような多雪地域 全域にわたる居住地の実態を概観し，地域性を解明 する中で，夫々の地域及び階層特性に応じた対策が 的確になされるようにして行くことは，雪国にとっ て大変有意義なものとなる。

以上のようなことから，当研究会は，今回，国の 内外に散在してしている雪国の居住実態や居住地整 借のための既存資料ないし文献を収集し，シソーラ スの作成及びキーワードの選定を通じて多数の文献 
の検索を可能とし，それを通して研究の全体像を示 し，この分野の研究の到達点と問題点を明らかにし ようとした。今後は更に進めて，多雪地における居 住地の再生を目指し，将来的には豊かな雪国の居住 地整備のための「マニュアル作り」及び「基準作り」 を志向し，その改善に努めるつありでいる。

\section{2. 作業の進め方}

調查研究期間は，昭和63年 4 月から平成元年 12 月 でる。その間に行った作業のフローを示すと，以 下の如くである。

\section{Step 1 調查研究計画の検討 S63. 4}

研究目的, 研究内容及び方法, 研究予算等

Step 2 文献収集

I. 日本建築学会 昭和 31 年 4 月～平成元年11月

II. 日本雪水学会 昭和17年 3 月～平成元年11月

III. 日本積雪連合 昭和 24 年 9 月～平成元年 11 月

IV. 克雪技術研究協議会等 昭和14年 平成元年

V. 日本雪工学会 昭和 60 年10月～平成元年11月

VI. 報告書・単行本・他 昭和 40 年頃 平成元年

Step 3 シソーラスの作成とキーワードの選定

I . 自然語の抽出

II. 居住地計画の研究ジャンルの検討

III. 居住地計画分野のシソーラスの作成

IV. 各文献へのキーワードの選定

Step 4 文献の分類と検索

I .カード型データベース文献検索ソフトへ文献 名及びキーワード等10項目を入力 使用パソコン機種 $\mathrm{PC} 98-\mathrm{XL}^{2}, 40 \mathrm{MB}$ 使用バソコンソフト Let'sアイリス 2.0

II. ジャンル別文献リストの出力

III. 「雪国の居住地計画」に関するジャンル別文 献集の作成

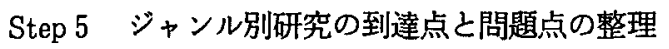

I 、ジャンル別年代別文献数の推移の把握

II. 空間整備を中心とした主要文献の抽出

III. ジャンル別の到達点と問題点の整理

\section{3. 作業の経過}

\section{3-1 研究組織・文献収集分担}

「雪国の居住地計画研究会」と称する研究組織は, 多雪地のブロックないし道県に居住し，雪国の居住 地研究に従事している 7 人の研究者で構成した。又， その研究の取りま之め及び研究連絡事務は，深澤大 輔 (豊田高専建築学科) が行った。

学会等の論文リストは, 深澤大輔が各学会の文献 目録ないし論文集を当り，作成した。

各道県に分散している資料や文献は，居住する地 域の道県・市町村及ひ研究活動等を通じて関係して いる諸機関から収集することにし，北海道は苫米地 司, 青森県・岩手県は月舘敏栄，秋田県は伊藤驍， 山形県・福島県は沼野夏生, 宮城県は桂久男, 新渴 県・富山県・石川県・福井県は青山清道・深澤大輔 を，夫々収集責任者とした。外国文献は，夫々の所属 する研究機関等の図書を中心に収集することにした。

\section{3-2 文献収集状況 ${ }^{\mathrm{i}) .2 .3 .3, .4 .5 .5 .6)}$}

学会等の論文及び手持ち資料のリストアップに大 変手間取り，全体に作業スケジュールは大幅に遅れ たが，日本建築学会・日本雪水学会・日本雪工学会 関係のリストアップ化は，ほぼ完了出来た。しかし， 今回は日本都市計画学会等の周辺学会及び海外の文 献収集までは手か迴らなかった。従って今後，その 㭪充をして行く必要がある。

各分担道県における資料及び文献の収集活動は， 分担實任者の努力によりかなりの成果が得られた。 今までにこれだけの国や県・市町村から出されてい る報告書等のリストアップがなされたことは恐らく 無いあの之思われ，大变貴重な文献資料が集まった ものと言える。しかし，北海道・青森県・岩手県・ 宮城県の文献収集が余り出来ておらず，又，収集出 来た県においてあやはり脱落文献が多数ある。従っ て、今後も多数の文献が出されるものと予想される ので，継続して補充に当る必要がある。

当初, 研究打合せを東京他で開催する予定でいた が，予算及び日程の関係から，書簡による交流に留 まった。 


\section{4. 作業の結果}

\section{4-1 文献の収集結果}

「雪国における居住地計画」に関する文献収集を 始めるに当って，先ず，「雪国における居住地計画」 とはどのような領域を守借範囲とするのか明解で無 くそのリストアップに困惑した。そこで，今回は， 当初加ら余り狭い枠組を設けず，雪又は雪国の住宅 及び住宅地・都市・地域の整備に関係していると思 われる文献絵てをピックアップすることとした。

その結果「雪国における居住地計画」に関する文 献として2,271件抽出できた。その内訳を示すと以 下の如くである。

I. 日本建築学会

\section{建築雑誌}

論文報告集

大会講演梗慨集

研究報告集 北海道支部

東北支部

北陸支部

関東支部

東海支部

II. 日本雪水学会

雪水

北海道の雪水

秋季(全国)大会講演予稿集

III. 日本積雪連合

IV. 克雪技術研究協議会 米沢市克雪プラザ紀要

$\mathrm{V}$. 日本雪工学会

\section{日本雪工学会誌}

雪工学シンポジゥム論文報告集 寒地技術シンポジウム 寒地環境工学合同シンポジウム

VI. 報告書・単行本・他 報告書 建設省

科学技術庁 コンサルタント等 北海道(札幌) 青森県

906件

80件 12 件 360 件 180 件 96件 155件 17件 6件 293件 109件 11件 173件 50件 20件 件 262件 42件 220 件 46 件 5件 377件 13件 4件 26件 11件 11件
岩手県

秋田県 41件

宮城県 1 件

山形県 62件

福島県 11件

新䳆県 111件

富山県 45件

石川県 12件

福井県 21件

長野県 6件 兵庫県 1件 一般図曹 65件 その他 243件 合計 2,271 件
しかし，その殆どは関連文献で，雪国の居住地の 空間整请に絞り狭い意味に限定して探すと，数は大 変少なく，主要と思われる文献は71件に留まった。 これは，雪国独自の居住地計画の必要性が認識され るようになったのは，最近のことであり仕方の無い ことと言える。しかし，最近，雪国の住民の生活環 境改善要求の高まりの中で, 国・県・市町村レベル でその改善の取り組みが，雪国の都市計画を意識し た基碟的なレベルで活発になっており，この動きは 注目に值する。そのような中で，今回特に，学会の みならず市町村や道県・国レベルでの報告書等が多 数リストアップされたことは，大きな成果と言えよ う。以下, 結果の概要を述へる。

\section{4-2 自然語の抽出}

前述した約2,000件の文献表題から自然語を抽出 したところ，約3,000語になった。このように用語 が多くなった原因は，少しのニュアンスの䕗いで造 語が使われ，複合語が多数派生しているためである。 例えば，同義語でも，a. 日本語で名称の異なるもの (ex. 宅地……画地)，b. 日本語と音訳語との関係 （ex. 現地調查……フィールト゚ワーク），c. 音訳法 の異なるもの(ex.プロジュクト……プロジェー)， d. 正式名之略語・略称・俗称との関保 (ex. 意味微 分……SD …...Semantic Differential）等が使われ ている。又，準同義語も，a. 概念の関連性が高いも 
の (ex. 理念……あり方), b. 同一の属性に対する異 なる観点の用語(ex。最高……最大)，c. 反義語 (ex. 発展……亭退)，d. 一般的・特殊的の関係(ex. 冬期… …寒候期）等,これでは，自然語による文献検索は 不可能である。

4-3 シソーラスについて ${ }^{2.8)}$

(1) キーワードとシソーラス

キーワード (Keyword) とは，「対象とする文献 の情報内容の内，必須な重要概念を短い言葉で的確 に表現したもの」と定義されている。索引語にキー ワードを使用する場合，むし，自然語（Free Term） である論文から任意に抽出すると，例えば，寒候期 は，一般的には冬期又は冬季であるが，俗には冬と る呼ばれ，OO月〜 $\triangle \triangle$ 月と書かれていたりする。 これに対する対語は暖候期・夏期・夏季・夏である。 このように一つの概念に対して幾つもの用語が使わ れているので，そのまま使うと検索回数が增え混乱 してしまう。従って, 索引としては用語の統制が当 然必要となって来る。

又，自然語の持つ曖昧性・多義性・不完全性等が 文献検索時の障害となる。ある検索テーマで連想さ れる用語を全て与えて検索するならば，検索システ ムは複雑化し，検索時間もかかり，検索漏れの生ず る恐れが多分にあるため，そこにシソーラスの必要 性が出て来る。

シソーラスとは，「情報検索システムで用いるキー ワードをコントロールし，キーワード間の意味的関 係を明示した検索辞典」である。ユネスコの定義に よると,「シソーラスとは，ある特定の知識領域を 包括的にカバーする，意味論的に，又，上下関係で 関連づけられた，コントロールされ，しかす，動的 な用語集を意味する」と述べられている。

(2) キーワードの標準化

(1)で述べたように，自然語の形でキーワードを索 引として使用すると，色々な不都合が生じて来る。 そのためにシソーラスに登録する登録語と登録の必 要のない非登録語とを区別する必要がある。索引語 として登録されたキーワードは，ディスクリプタ （標準キーワード）上呼ばれ，検索に使用されるも
のである。シソーラスの中に登録キーワードとして 収録されているが，対応するディスクリプタへのア プローチを容易にするための，索引語として使用を 禁止されているキーワードを非ディスクリプタ（非 標準キーワード）と言う。シソーラスとは，ディス クリプタ（標準キーワード）と非ディスクリプタ （非標準キーワード）間の関係，ディスクリプタ間 の階層（上位・下位）関係, 及びディスクリプタの 関連関係を明確に表示したものである。

(3) キーワードの選定とシソーラスの構成

「シソーラスは, ディスクリプタ（標準キーワー ド）と非ディスクリプタ（非標準キーワード）との 2 種のキーワード間の関係付けをした辞書である」 ので, 一定のディスクリプタと非ディスクリプタを 選定し，構成しなければならない。

ディスクリプタは，使用頻度・明瞭度・一般性等 を重んじて選定されるすので，単一概念を表わす言 葉と複合概念を表わす複合語や句からなるものであ る。

キーワードのディスクリプタと非ディスクリプタ の同義語・準同義語関係（USE／Used For)，上位 語・下位語 (Broader Term - Narrower Term), 及び関連関係（Related Term）を付けて，各見出 し語を50音順， $\mathrm{ABC}$ 順, 又はジャンル別に用語をグ ルーピングして配列したもので，それがシソーラス の本体となるすので ある。

例 見出し語のディスクリプタ》寒候期 非ディスクリプタ………… 期 冬期 上位語……………………... 下位語………………….... NT 根雪期間 関連語……………………. RT 冬, 暖候期 キーワードは，文献検索をするための検索語とし ての意味を持っている。「雪国における居住地計画」 に関連した文献数は，先に見た如く，2271件である。 今後，数倍に增加する可能性はあるが，その中から 目的の領域の研究に関連した文献が幾つ登録されて いるかを知り，又，その中から特に興昧のある文献 を抽出することが出来るためには，研究領域を示す ジャンル区分用キーワード（中項目）之，一般用キー ワード（小項目）之を選定して置くのが便利だと思 
われる。最終的に，一般キーワードで，文献が数件 に絞れるようにするためには，3〜5 個のキーワー ドを各文献に付与し，それにより検索作業を行える ようにする必要がある。そのためには,一つのキー ワードで平均して20件程度の検索が出来ることを目 安とすると，「雪国における居住地計画」分野にお けるキーワードの数は，100語を目安に選定して置 けば良い。

尚, 本研究では, パソコン本体としてNECのPC-


用し，文献検索用ソフトとして，カード型データベー スのLet'sアイリス 2.0を使用した。このシステム により，約 3 万件のカード型の文献検索が可能であ る。現在，雪工学の全分野の文献数は 1 万件程度, 雪水工学にまで拡大すると $1.5 \sim 2$ 万件程度になる と思われる。従って，当面このシステムで，その全 領域をカバーする文献検索が可能であり，今後，拡 張して行けると思われる。尚，1メガバイトのフロッ ピーディスクでは，約 1,800 件の文献しか扱うこと が出来ず物足りないが，ある分野に細分化すれば使 え，孫システムとして使うのには便利である。

\section{4-4 シソーラスの作成とキーワードの選定}

以上の検討を行い，14のジャンル，123のディス クリプタ（標準キーワード）よりなる「雪国におけ る居住地計画」に関するシソーラス（案）を作成し た。

今回選んだジャンル及びそれに関連したキーワー ドを示すと以下の如くである。尚, ジャンルの後に 示されている数字は, ジャンル名称も含むキーワー ドの数である。

\section{1 研究基礎 (5)}

研究方法, 研究理念, 研究総論, 克雪全般 02 対象地域 (7)

北海道, 東北, 北陸, 内陸, 世界, 無雪地域

03 積雪 - 降雪 (13)

寒候期，寒泠地区，多雪地区，降雪樑，積雪深， 積雪形状，積雪変態，屋外気温，風速，自然熱， 雪情報, 空中写真 04 屋根雪処理 (16)
屋根形，屋根積雪，屋根材，積雪形状，建築雪 対策, 雪荷重, 耐雪構造設計，屋内気温，暖房， 結露, 経済性, 落雪型, 載雪型, 融雪型, 雪害 05 雪国居住 ( 5 )

居住者，住まい方，居住水準，定住計画

06 雪国建築 (8)

間取り，住宅規模，多雪地住宅，寒冷地住宅， 建築計画, 維持管理, 住宅需給

07 克雪建物配置 (4)

建築規制，配置設計，環境計画

08 居住地雪処理 (16)

吹溜り, 宅地雪処理, 車庫雪処理, 通路雪処理, 道路雪，流雪淟，施工，雪輸送，眝雪，住民参 加, ホープ計画, 克雪タウン計画, ニュータウ ン計画，モデル計画，耐雪度

09 多雪宅地 (7)

空間構成，区画計画，街区計画，地区計画，宅 地開発，宅地需給

10 多雪居住地 (7)

居住地型，密集市街地，計画住宅地，スプロー 儿住宅地, 農村集落, 居住地水準

\section{1 多雪地景観 (4)}

景観整備，景観要素，伝統建築

\section{2 多雪地域 (4)}

地域性，都市構造，都市計画

13 多雪地法制度 (6)

建築基準法，都市計画法，集落地域整備法，寒 住法, 税法

14 その他（21）

一般図書，リモートセンシング，地ふぶき，な だれ，凍上対策，交通システム，道路交通，鉄 道，航空機，地滑り，崖崩れ，冬期野外教育， レクリエーション，農業，林業，その他

以上は現段階において収集された文献の表題を基 に整理したあのであり，今後，文献検索をしてみて 不都合が出て来たり，文献数が増え，研究領域や内 容が変化するのに対応し，改訂して行く必要がある。

尚，「雪国における居住地計画」分野におけるシ ソーラスの作成上の注意事項及び問題点を整理する 
と以下の如くである。

(1)「雪国におりる居住地計画」分野の研究者だけで なく，㕕く克雪まち・むらづくりに関係する人々 にコンセンサスの得られるすのとする必要がある。

(2)「雪国における居住地計画」研究の主題カテゴリー が不明確なため, シソーラスの骨格を描くのが難 しい。

(3)研究や実態調查の意図や到達段階，展望の不明解 な論文や報告が多く，かつ，多項目にわたってい るため，分類やキーワードの選定は，膨大な元論 文を読み，抄訳を行う等の作業を行わないと困難 である。

(4)「雪国におりる居住地計画」研究では, 自然語 （Free Term）を多用しており，研究者個人の思 いを用語に込めていたりする。従って，その統一 をはかることには抵抗があり，その選定は極めて 困難である。

(5)「雪国における居住地計画」研究とは言っても名 ばかりで,どのようにしたら計画の具体化が実現 するか，その体系化がなされていない。従って， 標準キーワードとして選定出来る計画技術用語が 確定していない。

(6)「雪国における居住地計画」研究は始まったばか りで，研究側よりも行政側から住民の要望に応え る形で積極的に取り組みが試行されている。しか しその多くは，市町村ないし県レベルでの比較的 狭域での取り組みで，相互の情報交換や積み上げ になっていない。徉って, シソーラスの作成を通 じて視野を拡げ，計画研究者ないし行政官として の自覚を高め，実力を付けて行く必要がある。

(7)「雪国における居住地計画」の研究領域は，新し く漸く始まったばかりである。今後の研究発展を 期待する時, シソーラスのような体系だった枠組 を考え，研究の積み上げを計って行けるような体 制を整えることは，研究者・行政官・住民にとっ て重要な課題である。

\section{4-5 カード型文献検索テータベースの作成}

今回収集出来た 2,271 件の文献データをカード型 データベースソフトのLet'sアイリス 2.0 を使い, 1
表題 - 単行本, 2 副題， 3 著者名， 4 雑誌・機関誌, 5 巻, 号, 6 発行年月, 7 揭載頁・番号, 8 発行斥, 9 キーワード，10備考の10項目について入力した。

その結果は, 123のキーワードにより検索しファ イルし，文献集として住宅総合研究財団より，平成 2 年 3 月に研究報告書として刊行される予定である ので，そちらを参照して頂きたい。

ところで, パソコン・ディスプレー上では，実際 は，検索する目的を较って行えば，功なの威力を 持っていると言えるが, ジャンル別に幾つかのキー ワードにより検索した結果をファイルした文献集の 形では，数が多過ぎてどんな文献があるのかを頭の 中で理解するのは至難の技のようである。従って， 一番良い方法は，ある文献を挆したいと考えれてい る人自身が自分で幾通りかの検索を行い，所要の文 献がピックアップ出来るまで検索作業を行うことで ある。しかし，それも現実的には現段階では不可能 に近いので，目的を聞いて代行する形を取らざるを 得ないであろう。この場合す誰が代行するのかが問 題となる。最近, 日本雪水学会ではパソコン通信に よる雪情報センター（仮称）の設立の検討が行われ ており，日本建築学会ですキーワードを付けること を義務付けて，学術情報センターに加入し，1990年 の大会論文から順次データベース化を実施して行け るよう，検討がなされている。このような動きから 見ると，今回は「雪国における居住地計画」を中心 にデータベース化を行ったが，今後，全雪工学分野 に拡大し，日本雪工学会として文献情報サービスを 行っていける体制づくりの検討を開始する必要な時 期に来ていると言えよう。

尚, 今回の文献集には，幾つか表題が長いため末 尾が入力出来なかったものや，発表年代が不明な文 献が含まれているが，この他入力して気が付いた問 題点を整理すると，以下に示した如くである。

(1)造語や俗語・現地語等が多用されており，一つの

事柄に関して幾つもの用語が使われている。

(2)表題が短か過ぎたり，長くてもその表題が悪かっ たりして，その文献の内容が読み取れない文献が ある。

(3)表題の用語の使い方が内容から見て不適切であっ 
たり，誤っていると見られる文献がある。

(4)表題之副題の順序が逆になったり，その1・その

2 等の表示が，表題に付いたり副題に付いたりし

ていて，統一されていない。

(5)論文と単行本を同列に扱っているため，1表題・

単行本と 4 雑誌・機関誌の欄に若干そごが見られ る。

(6)キーワードの付け易い文献と付け難い文献とがあ る。

\section{5．「雪国における居住地計画」の到達点} 一ジャンル別年代別文献数の推移を通して一

今回は，各文献の内容について検討する時間が無 く，2,271件の「雪国における居住地計画」に関す る文献をカード型データベース化したに留まった。 そのような段階であるが，今回登録出来た文献につ いて，ジャンル別年度別にその数の推移を見ると， 表ー1の如くであった。

年代別に文献数の推移を戦後について見ると，昭 和38（1963）年が三八豪雪の影響で15件と二ケ夕に なっているが，それ以外は昭和43（1968）年まで一 ケタ台で，余り多くない。しかし，昭和44（1969） 年以降は二ケタ台が続き，五六蒙雪と騒がれた昭 和56（1981）年以降は，三ヶ夕台に上り，59〜61年 の 3 年連続豪雪により昭和60（1985）年には218件 となり, 平成元 (1989) 年には日本雪工学会大会が 2 回開催された影響加ら，年間で225件にも達して いる。このように年代別に見ると，豪雪年を契機に 克雪に対する関心が社会的にも高まり，文献件数が 增える傾向が同える。

次に，ジャンル別に文献件数の多い順に見てみる と，1位「屋根雪処理」521件， 2 位「雪国建築」 471件， 3 位「居住地雪処理」430件，4 位「積雪 降雪」188件，5位「多雪居住地」162件，6位「雪 国居住」157件，7位「その他」85件，8位「多雪 宅地」67件，9位「多雪地景観」61件，10位「研究 基礎」47件，11位「多雪地域」28件，11位「多雪地 法制度」28件，13位「克雪建物配置」12件，14位
表ー 1 「雪国における居住地計画」に関する 文献数の推移 （単位 : 件)

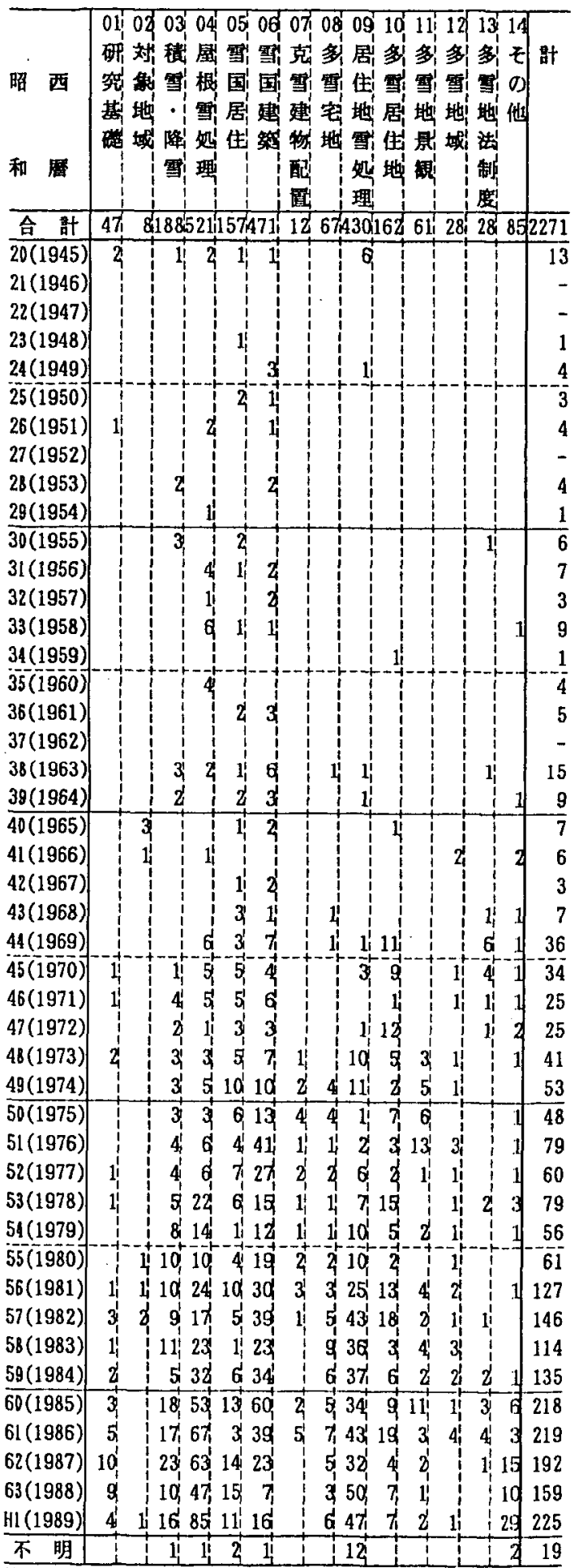

注)昭和20(1945)年の数字はそれ以前を含む。

平成元(1989)年は霨工学シンポジウムを2回開催。 


\section{「対象地域」8件の如くであった。}

「克雪建物配置」は12件しか見あたらないが，相 隣関係を問題にするような具体的な建築計画ないし 都市計画の基準作りに関する実例報告や，考察又は 提案等は，「屋根雪処理」や「居住地雪処理」等に 実際には取り込まれて検討されていると言える。そ のような研究が「雪国における居住地計画」を推進 して行くためには，多くなることが期待される。

文献数が二ケ夕になっている年をピックアップし， その増加した原因を考察すると，以下の如き状況が 同える。

昭和44（1969）年に,「多雪居住地」が現れてい る。これは、三八豪雪を契機に北陸の豪雪地帯の豪 雪問題が社会問題化し，急速に多雪地の居住地に関 する関心が高まり，その動きに呼応して台頭してき た研究分野である。又，これは多雪地の居住地の害 態を解明する分野と言え，全体の数は少ないが, 昭 和47（1972）年に12件，昭和53（1978）年に15件, 昭和56（1981）年に13件，昭和57（1982）年に18件， 昭和61（1986）年に19件の如く，豪雪年の後に多く なる傾向が見られる。

昭和48（1973）年に，「居住地雪処理」が現れて いる。この推移は, 翌年の昭和49（1974）年には11 件となって維持しているがその後は減少し，再び, 昭和54（1979）年からは毎年10件以上となり，昭和 57 (1982) 年と昭和61（1986）年には43件と増加し， 昭和63（1988）年には50件に達している。

この增加は，高速道路や国県道等の主要幹線道路 の雪処理や新幹線雪対策が進んだ中で，居住地の雪 処理対策が相対的に取り残された感が多雪地の居住 者に強くなり，社会問題化し出したことと，最近の 增加は，「雪に強いまちづくり」と「雪に強い家づ くり」をベースとする建設省の「ホープ計画」や 「克雪タウン計画」の推進等があり，その関係の報 告書等の文献が急増していることと呼応している。

昭和49（1974）年に，「雪国居住」と「雪国建築」 が現れている。

「雪国居住」は，上述の「多雪居住地」の中身を 見る分野之言え，昭和56（1981）年に10件，昭和60 （1985）年に13件，昭和62（1987）年に14件，昭和
63 (1988) 年に15件, 平成元 (1989) 年に11件の如 く，比較的安定的に研究が継続されている。

「雪国建筑」は，昭和49（1974）年以降，昭和63 （1988）年の7件を除いて二ケタが続き，昭和60 (1985) 年には60件にす達している。これから、豪 雪年を契機に建築学会でも，北海道や東北・北陸の 建築に関する論文発表数が激増する傾向が同える。

昭和51（1976）年になると「多雪地景観」が現れ ている。これは，建築界全般にポストモダンの動き が顕著となり，伝統的な町並に関して関心が高まる 中で，その調和をどのように計って行ったら良いか が問題化し，雪国でも同様に，伝統的な建築の保存 P町並の景観を見直してみようとする研究が出だし たものと思われる。しかし，その後は，昭和60 （1985）年に11件見られる以外，一ケ夕の文献しか 見られず，やや停滞的と言える。

昭和53 (1978) 年には「屋根雪処理」が現れてい る。それ以前は，雪荷重や自然骬落に関する論文発 表が見られた程度であったが，急速に落雪型・載雪 型・融雪型の直接的ないし間接的な「屋根雪処理」 に関する文献が増え，平成元 (1989) 年には，雪工 学会大会が 2 回開催されたことが影響し，85件にあ 達している。このように最近急速に研究報告が増え ている原因として，次のようなことが考えられる。

豪雪年が続いたことから建築研究者の中において 耐雪構造設計に関する論文が増えている。

行政側からは「雪に強い家づくり」や「優良木造 住宅」に対する取り組みが開始され，「屋根雪処理」 を中心とした克雪型住宅に対する融資枠の拡大等が 見られるようになっている。

更に我国のハイテク産業化がこの分野にも触手を 伸ばすようになり，ハイテク技術を駆使した製品及 びシステム開発が行われ，メーカーが入り乱れて凌 ぎを削ると言う状況が見られるようになっている。 このため, 各種の融雪型を中心とする屋根雪処理方 式の技術開発が行われ出した。

以上のような動き等と呼応し，「屋根雪好理」に 関する論文の数が飛躍的に増加したものと見られる。 昭和55（1980）年には，「積雪・降雪」が現れて いる。この分野は戦前から地道に研究が続けられ, 
そのデータをまとめた報告書等が出されていたが， 五六豪雪及び59年からの3 年連続豪雪を契機に，そ の対策の基礎データづくりが盛んとなり，気象記録 や解析文献などが急増している。

昭和62（1987）年になると，「研究基礎」と「そ の他」が現れている。これは，建築及び土木分野の 研究者を中心とした日本雪工学会が設立され，そこ で活発にシンポジゥム等が開催されるようになり， 雪工学に関する基礎的ないし居住地計画の関連分野 の研究報告が多数なされるようになったためと考え られる。

以上に対して,「対象地域」3件/8（1965），「多 雪地法制度」6件/28（1969），「多雪地域」6 件/28 (1969)，「多雪宅地」9件/67（1983），「克雪建物配 置」5件/12（1986）が，年間10件以上の文献数に 達したことの無い研究沵野となっている。これらの 分野は，「雪国における居住地計画」研究に较った 場合,「多雪地法制度」や「克雪建物配置」は大变 重要な分野と言え，今後これらの研究分野の研究 論文や報告書の刊行む進むことが期待される。

\section{6. あとがき}

我国の多雪地帯における居住地の雪による生活珐 迫の状況は世界に類例を見ない。我国の高度経済成 長に伴い雪国の生活構造む大幅に変化したが，その 今日化策は大变遅れている。しかしながら，その居 住地の整備に関し，どれ位研究機関と行政により， 取り組まれて来ているのか，断片的な形でしか紹介 されて来なかった。今回，このように戦後の殆ど全 期間について，更に多雪地における国・道・県や市 町村の報告書等を含んで全国的な規模で網羅的に明 らかにされ，また，未だ，脱落している文献が多く， 今後とも収集活動を続け落ちの少ないものにして行 く必要があるが，2,271件に及る゙文献が，シソーラス を作成し，キーワードにより検索出来る形に整理出 来たことは，今後の「雪国における居住地計画」の 展開にとって，大变意義のあることと信ずる。

今回は「雪国における居住地計画」に関する研究 の内容にまで踏み込み，到達点を示し，今後解明す べき課題を明らかにするまでには到れなかった。今 後, 完成したこの文献検索システムを活用し, 文献
をピックアップしながら目を通し，ジャンル別に到 暹点を探り，今後この分野の研究の進むべき方向を 明確にしたいと考えている。

このような文献研究に当り，多数の方から文献り ストを寄せて頂いたり，貴重な文献を奇贈して頂い た。又，文献のカード型データベースへの入力には， 高橋敬子さんの手を煩わせた。末尾であるが,これ らの方々に感謝の意を表して終りとしたい。

\section{参考文献}

1）絵目録（昭和 $31 \sim 40$ 年），建築雑誌・論文報告 集・研究報告，206pp，昭和 42 年 4 月，日本建 築学会.

2 ）総目録（昭和 $41 \sim 50$ 年）, 建築雑誌・論文報告 集・大会学術講演梗概集・支部研究報告, 437 $\mathrm{pp}$ ，昭和54年 1 月，日本建築学会.

3）総目録 (1976 1985)，建築雑誌・論文報告集 大会学術講演梗概集・支部研究報告, $831 \mathrm{pp}$, 昭和 63 年 5 月，日本建築学会.

4) 最近の雪水に関する研究展望（1950～1958）, 雪水の研究No. $3,139 \mathrm{pp}$ ，昭和35年 9 月，日本 雪水学会.

5 ) 雪水の研究展望之文献目録（1959～1968）, 雪 水, $35,1 \sim 12,1973$, 日本雪水学会.

6) 雪水の研究展望之文献目録 $(1969 \sim 1978)$, 雪 水の研究No. $6358 \mathrm{pp}$, 昭和57（1982）年 2 月, 日本雪水学会.

7) 園田桂一 : シソーラスについて（解説），土と 基礎，土質工学会.

8 ）深澤大輔 : 農村住宅計画のキーワードとシソー ラス，農村住宅研究の科学的規準作成にむけて一 研究展開の方向一, 42-69pp, 1984.10，(社） 日本建築学会 農村計画委員会住宅部会.

\section{<研 究 組 織>}

\begin{tabular}{|c|c|c|c|}
\hline \multirow{2}{*}{$\begin{array}{l}\text { 主査 } \\
\text { 委員 }\end{array}$} & 深澤大輔 & 豊田高専 & 助教授 \\
\hline & 桂 久男 & 東北大学 & 教授 \\
\hline & 伊藤 驍 & 秋田高専 & 教授 \\
\hline & 青山清道 & 新䳆大学 & 助教授 \\
\hline & 沼野夏生 & 国立防災七 & センター新庄支所 \\
\hline & 苫米地司 & 北海 & 業大学 助教授 \\
\hline & 月舘敏栄 & 八戸工業大 & 講師 \\
\hline
\end{tabular}

